\title{
Fake news portrayals of stem cells and stem cell research
}

\author{
Alessandro R Marcon ${ }^{1}$, Blake Murdoch ${ }^{1}$ \& Timothy Caulfield ${ }^{*}, 1$ \\ ${ }^{1}$ Health Law Institute, Office 468, Faculty of Law, University of Alberta, 11189 Avenue, Edmonton, Alberta T6G 2H5, Canada \\ * Author for correspondence: Tel.: +1 780492 8358; caulfield@ualberta.ca
}

\begin{abstract}
Aim: This study examines how stem cells and stem cell research are portrayed on websites deemed to be purveyors of distorted and dubious information. Methods: Content analysis was conducted on 224 articles from 2015 to 2016, compiled by searching with the keywords 'stem cell(s)' on a list of websites flagged for containing either 'fake' or 'junk science' news. Results: Articles contained various exaggerated positive and negative claims about stem cells and stem cell science, health and science related conspiracy theories, and statements promoting fear and mistrust of conventional medicine. Conclusion: Findings demonstrate the existence of organized misinformation networks, which may lead the public away from accurate information and facilitate a polarization of public discourse.
\end{abstract}

First draft submitted: 18 April 2017; Accepted for publication: 2 August 2017; Published online: 8 November 2017

Keywords: content analysis $\bullet$ fake news $\bullet$ misinformation $\bullet$ stem cell research • stem cells

Fake news is not a new phenomenon [1,2], but it is attracting significant attention in the current media landscape. Indeed, we live in what is often described as the 'era of fake news' [3,4], where claims about which sources and what stories constitute fake news are not only abundant, but are at times made by powerful political and corporate figures [5-8]. One recent analysis showed that in the most recent American elections, stories from fake news websites were shared more often on Facebook than those from major news sources [9]. The growth of fake news has created widespread challenges for educators [4], public media policy advisors [10], internet-based media platforms [11-13], scientists $[14,15]$ and the public. A recent study by the Pew Research Center shows that despite people's confidence in their abilities to detect fake news, almost two-thirds of the American public admit that fake news is causing confusion, and nearly a quarter admit to having (inadvertently) shared fake news stories [16].

One key issue contributing to these current trends is the difficulty in clearly defining what counts as fake news. Distinguishing sound, verifiable, and valuable news sources in the context of science reporting is a complex task as even many popular and established sources have been shown to write in a style that exists on a continuum between 'evidence-based' and 'compelling to readership' [17]. There are many forces that contribute to less-than-ideal science reporting, including the current research incentive frameworks that may contribute to the generation of science hype [18,19], social media [20] and pressure on the popular press to make content positive and engaging [21].

Fake news can be defined as news that comes from a disregard for sound, factual evidence in favor of 'distorted, decontextualized or dubious information' [22]. It has also been associated with a focus on creating clickable, revenuegenerating content [23]. In the realm of fake news, 'clickbait', the use of headlines containing heavily-sensationalized language with the goal of generating clicks, is prevalent [24-28]. Although creators of fake news have sometimes stated in interviews that they are motivated in part by political or ideological objectives, their websites and articles have proven in some cases to be substantial sources of profit $[23,29,30]$. There have also been efforts to identify specific websites and news sources as drivers of fake news [31]. Indeed, Facebook hired the organization Snopes to carry out this very process on its social media site [32]. Similarly, Professor Melissa Zimdars' work identifying web domains known to spread misinformation has informed the methods of this research.

The spread of misinformation, including fake news, has a significant impact on the discourse around health. Access to and proper understanding of good health information improves health outcomes [33]. If individuals are already hesitant or untrusting of a health product or service, confirmation bias will likely cause them to seek out validating information [34], which fake news can provide in the absence of real evidence. This contributes to the 
creation of online echo chambers [35]. Belief in health misinformation can have an adverse impact on health behaviors and outcomes [36]. This is perhaps most evident in the case of vaccination, where problematic coverage in traditional and social media have likely contributed to increased vaccine hesitancy [37-40]. False balance in media reporting and public exposure to conspiracy theories can have lasting impacts on attitudes and healthcare decisions [41-44]. Moreover, the effects of misinformation can continue after correction, as 'belief echoes' relating to the original misinformation can persist and continue negatively shaping individual attitudes [45,46]. This is important in the context of public opinion about stem cell research. The pervasive presence of misinformation related to stem cells can influence the wide range of perceptions that individuals have. An exaggeration of benefits or risks, especially when accompanied by highly inaccurate information, can only serve to confuse or mislead the public on issues related to stem cells, including the readiness of novel stem cell interventions for clinical application. Furthermore, proliferation of false information could potentially lead to increasing polarization of viewpoints among individuals and communities. These effects could have an impact on policy.

Given the powerful effects of misinformation, stem cell-related articles from untrustworthy or fake news sources deserve closer study [46]. Past research has found widespread online marketing of unproven therapies [47], and associated misleading claims used by clinics $[48,49]$. Other research has found that media sources largely present unproven stem cell therapies in an uncritical manner [21]. Problematic representations of stem cell policy in the media can have multiple effects, including hyping the current or future benefits of the science or distorting the associated risks and ethical problems. In this study, we examine recent stem cell-related articles from web domains known to spread misinformation. Here, the key is not to determine the overall representation of stem cells in the media, but to focus on unreliable online sources to determine the most common topics discussed, the kinds of claims made, and the themes that commonly arise.

\section{Methods}

To create a database of relevant articles, and to ensure reproducibility, we first accessed an open source list of websites compiled by Professor Melissa Zimdars, whose 'OpenSources' project provides "a continuously updated database of information sources for developers to leverage in the fight against fake, false, conspiratorial and misleading news" [31]. Once Zimdars' team determines that a website falls somewhere on this spectrum, it is given one of the following 12 labels: 'Fake News'; 'Satire'; 'Extreme Bias'; 'Conspiracy Theory'; 'Rumor Mill'; 'State News'; 'Junk Science'; 'Hate News'; 'Clickbait'; 'Proceed with Caution'; 'Political'; 'Credible'. Keeping in mind that fake news is a nascent and evolving social phenomenon with a broad range of characteristics, we observed that 'Fake News' labelled sites are defined by OpenSources as "sources that entirely fabricate information, disseminate deceptive content, or grossly distort actual news reports" and 'Junk Science' labelled sites are defined as "sources that promote pseudoscience, metaphysics, naturalistic fallacies and other scientifically dubious claims" [31]. We determined that sites labelled as both "Fake News' or 'Junk Science' constitute part of what is commonly defined as fake news - the former related to news events generally and the latter focused specifically on health and science topics - and that a combination of sites with both labels would provide us with an ample dataset of articles relevant to the spreading of distorted or dubious stem cell-related information. Because sites labelled 'Clickbait' or 'Conspiracy Theory' could also be considered as part of the fake news realm, our list should not be seen as encompassing all elements of fake news, but rather a sample of some of the relevant discourse.

In February 2017, using the Google search engine, the terms 'stem cell' and 'stem cells' were searched in each of the 'fake' and 'junksci' web domains using the following search query: search term site: URL. All websites that contained a hit were added to another list. The same Google search was then performed a second time with the time period set from 1 January 2015 to 31 December 2016, and all corresponding article URLs from the websites were added to the final list for analysis. The initial dataset included 238 articles from 26 different websites.

Our objective was then to carry out content analysis on each of the articles using inductive and deductive methods [50]. That is, we first designed an initial coding frame, which we then modified after analyzing a sample of approximately $25 \%$ of the articles. Our initial frame contained aspects of the discourse we wanted to analyze, including article topics as well as procedures or activities with which stem cells and stem cell research were associated. We also wished to determine the presence of specific references to scientific studies, and the tone of the article with respect to stem cells and/or stem cell research. Incorporating findings from our sample allowed us to more specifically align the frame to the discourse and also to include coding for the presence of messaging that seemed to promote "fear, distrust or suspicion", as we observed a considerable amount of this characteristic during initial sampling. A finalized coding frame was then created and implemented. Our finalized coding frame included: the 
central topic of the story; the specific topics associated with ethical, legal or social issues if they happened to be the central topic; the topic, procedure or activity associated specifically with stem cells or stem cell research; the manner in which stem cells were mentioned with regards to use; the tone of the article with respect to stem cells or stem cell research; whether specific science studies were mentioned in articles; if so, whether specific information concerning these studies were provided (journal, institution, authors, etc.); whether statements regarding efficacy were claimed by the authors or articles with respect to the studies; whether statements/claims suggesting fear, distrust, or suspicion appeared in the headlines; and lastly, whether statements/claims suggesting fear, distrust, or suspicion appeared in the rest of the article. Articles where 'stem cell' or 'stem cells' appeared in the comments were removed from the dataset, as were duplicate articles with the same URL. Coding was then undertaken on a dataset of 224 articles from 24 domains. In some articles 'stem cell' or 'stem cells' appeared only in name or as part of a description irrelevant to the topic of the article. In these instances, of which there were 39, the remainder of the frame was not applied to the article. After all exclusions, the final dataset included 185 articles across 22 web domains.

After completion of coding, to provide quality assurance, the primary coder coded just under $20 \%$ of the secondary coder's articles and compared for consistency. Of the 24 articles analyzed, differences were found in a maximum of two articles across all categories, with the exception being the presence of statements suggesting "fear, distrust or suspicion", where discrepancies were found in four. As such, agreement was found in over $90 \%$ of the articles in all categories and still over $80 \%$ in what might be considered the most subjective category.

Lastly, because it was observed during coding that articles frequently referenced other health websites and blogs (in addition to well-known media outlets such as National Public Radio, New York Times, the Guardian, CNN, ScienceDirect, Scientific American, etc.), we noted all cases where articles referenced 'sources' as either authors, or in lists at the end of the articles. Because a vast amount of hyperlinks appeared in the articles, links embedded in the body of the article were not individually opened and included in the counting. As such, our tabulation of sources or cross-referenced websites contributing to the article should be observed as a minimum total of external websites referenced.

\section{Results}

Of the 185 articles from 22 different web domains, well over half were from one of beforeitsnews.com (31.35\%), naturalnews.com $(20.00 \%)$ or collective-evolution.com (11.89\%; see Table 1$)$. Three other domains contributed an additional $21.62 \%$, and the remainder of the domains contributed fewer than five articles each to the sample.

The most common central topics (see Table 2) of the articles were science and research not related to cloning (cloning defined for the purposes of analyzing this corpus as reproductive cloning of entire organisms; 27.57\%), therapies to treat diseases or ailments $(23.78 \%)$, ethical, legal and social issues including government and institutional actions and policies (22.70\%), and products or substances for health promotion or anti-aging (20.00\%; e.g., "This combination could save lives: black pepper and turmeric [anticancer \& weight loss]"; "Curcumin eradicates brain protein fragments to fight Alzheimer's disease"). For articles where the focus was ethical, legal and social issues, unethical research (59.52\%; e.g., "Fraud in medical research: a frightening, all-too-common trend on the rise"; "NIH prepares to lift ban on experimental research that could create animals with part-human brains, consciousness", "Horrifying! Part human, part animal hybrid embryos! [Videos]'), and harmful government policies and actions (38.10\%) were the most common topics mentioned, followed by crime and nefarious activity unrelated to the government (35.71\%) and religious themes (26.19\%).

The most common topics associated with stem cells or stem cell science were cancer (28.65\%), growing or fixing body parts (22.16\%; e.g., teeth, structures in the eye to regain sight, bones), general health or wellness related to diet (18.92\%; e.g., "Neuroscientist Shows What Fasting Does to Your Brain \& Why Big Pharma Won't Study It", "9 Things That Happen When You Stop Eating Meat'), and stopping or reversing noncosmetic aging processes (11.89\%; e.g., "Scientists Have Successfully Reversed the Aging Process Using Experimental Gene Therapy", "Scientific Studies Bring Further Evidence That Young Blood Can Reverse Aging"). The manner in which stem cells were mentioned was most commonly in relation to stimulation of existing or growth of new stem cells $(40.54 \%)$, followed by injection of stem cells (22.70\%; examples include bone marrow stem cell injection into the retina and optic nerve for vision, stem cell injections into the brains of clinically dead patients to supposedly bring them back to life) and treating harmful stem cells by removal, reduction, destruction, among others $(22.16 \%$; harmful stem cell types were usually not specifically explained or categorized, but cancer types mentioned included, e.g., acute myeloid leukemia and colorectal liver metastases). Stem cell types and/or sources were usually not mentioned, though this was occasionally 
Table 1. Articles per web domain.

\begin{tabular}{|c|c|c|}
\hline Web domain & Articles & $\%$ \\
\hline beforeitsnews.com & 58 & 31.35 \\
\hline naturalnews.com & 37 & 20.00 \\
\hline collective-evolution.com & 22 & 11.89 \\
\hline healthnutnews.com & 14 & 7.57 \\
\hline healthimpactnews.com & 12 & 6.49 \\
\hline consciouslifenews.com & 14 & 7.57 \\
\hline galacticconnection.com & 4 & 2.16 \\
\hline naturalblaze.com & 4 & 2.16 \\
\hline collectivelyconscious.net & 4 & 2.16 \\
\hline thecontroversialfiles.net & 3 & 1.62 \\
\hline Ancient-code.com & 1 & 0.54 \\
\hline ewao.com & 1 & 0.54 \\
\hline newsbbc.net & 2 & 1.08 \\
\hline dailyheadlines.net & 1 & 0.54 \\
\hline americankabuki.blogspot.ca & 1 & 0.54 \\
\hline newswithviews.com & 1 & 0.54 \\
\hline libertyblitzkrieg.com & 1 & 0.54 \\
\hline clashdaily.com & 1 & 0.54 \\
\hline pakalertpress.com & 1 & 0.54 \\
\hline thelastgreatstand.com & 1 & 0.54 \\
\hline thetruthseeker.co.uk & 1 & 0.54 \\
\hline in5d.com & 1 & 0.54 \\
\hline Total & 185 & 100.00 \\
\hline
\end{tabular}

observed, for example, bone marrow-derived stem cells in articles about stem cell injections and embryonic stem cells in articles raising ethical concerns about stem cell scientific research. Stem cells were largely portrayed as beneficial $(61.62 \%)$ and sometimes as harmful $(23.24 \%)$, the latter often in the context of cancer-causing stem cells.

Among the articles, 58.38\% mentioned specific scientific studies, and $41.62 \%$ did not. Of the 108 mentioning studies, $84.26 \%$ provided at least some information about the study's authors, institution, or journal. About $15.74 \%$ mentioned a study without defining its origin in any traceable way. Of the articles mentioning studies, $62.96 \%$ made additional claims as to the efficacy of that science. Examples of claims of efficacy are noted in Table 3.

Of the articles relevant to stem cells, $16.22 \%$ of headlines and $26.49 \%$ of main texts contained statements or claims that appeared to be focused on creating fear, distrust or suspicion. Examples of headlines and article text of this nature are in Table 4.

When determining the sources contributing to the articles, in 123 instances, articles referenced health blogs, health websites, or alternative media outlets which we did not recognize as well-known popular news media (such as New York Times, CNN, The Guardian, The Daily Mail, etc.), science related media (such as Scientific American, Popular Science, ScienceDirect, iO9, etc.), or academic journals (such as Nature, JAMA, links in academic citation formats, or PubMed links, etc.). Of these 123 instances, 67 (54.47\%) were found to be from four domains: NaturalNews, Collective Evolution (two 'junksci' websites included in our study), Mercola (Dr Mercola) and GreenMedInfo. Additional domains included websites with names such as: The Daily Sheeple, Truth is Scary, The Renegade Pharmacist, Neseara-Republic Now-Galactic News, Top Healthy Life Advices, The Anti-media, among others. It was beyond the scope of our study to assess the validity of each website sourced.

To summarize: the data show that $43.78 \%$ of the articles were focused on either a product, substance or therapy, while $29.73 \%$ were focused on reporting about science or research. Since $63.14 \%$ of the articles mention stem cells in relation to their stimulation, growth or injection, $61.62 \%$ of the articles present stem cells as beneficial, and the majority of articles do not contain statements focused on creating fear, distrust or suspicion, we can reasonably conclude that the overall trend of the articles is to positively promote stem cell-related products, therapies and discoveries, whether unproven or otherwise. 
Table 2. Coding frame results.

1. What is the central topic of the story?

Number

(a) Therapies to treat disease/ailment

(b) Products or substances for health promotion or anti-aging

(c) Focus on science or research not related to cloning

(d) Focus on science or research related to cloning

(e) Ethical, legal and social issues (including

government and institutional actions and policies)

(f) Business development/growth

(g) Other

Total number of articles

2. If (e) in \#1, what topics are associated (choose all that apply)?

(a) Religious themes (e.g., reference to religion entities such as God, Satan, etc.)

(b) Harmful government policies/actions (including 16

criminal activity, abuses of power)

(c) Constructive government policies

(d) Crime/nefarious activity unrelated to government 15 (including actions by corporations, etc.)

(e) Unethical research

(f) Other (fill in which)

3. What is the nature of the topic, procedure or activity associated with stem cells or stem cell science (choose all that apply)?

(a) Stopping or reversing noncosmetic aging processes

(b) Cloning

(c) Harvesting stem cells

(d) Creating or experimenting on human embryos

(e) Growing or fixing body parts (fill in which)

(f) Creating new creatures/reviving old ones (extinct animals, human-animal mixes, 'chimeras', etc.)

(g) Cancer-related

(h) Aesthetic or cosmetic

(i) Testing products

(j) General health or wellness related to diet

(k) General health or wellness related to exercise

(I) General health or wellness related to

complimentary and alternative health

(m) Not relevant: 'stem cells' or 'stem cells' just appears in name, merely appears as description without elaboration, or doesn't appear at all

(n) Other

4. How are stem cells being mentioned in the article with regards to use (choose all that apply)?

(a) Stimulation of existing stem cells or growth of new 75 stem cells (regeneration, restoration, 'repair', etc.)

(b) Injection of stem cells 42

(c) Applying stem cells to body noninvasively (topical 3 creams, etc.)

(d) In relation to cloning

(e) Depletion of healthy stem cells

(f) Treating harmful stem cells by removal, reduction ('destroying'), hindering growth of, among others.

(g) Other
44

37

\section{1}

4

42

1

185

Number

11

16

2
15

25

1

Number

22

8

5

14

41

24

53

6

6

35

1

10

39

19

$10.27 \%$

Number

Percentage of relevant articles $(n=185)$

$40.54 \%$

$22.70 \%$

$1.62 \%$

$3.78 \%$

$3.78 \%$

$22.16 \%$

41

$12.43 \%$ 


\section{Table 2. Coding frame results (cont.).}

5. Are 'stem cells' or the 'stem cell research' presented as something beneficial or something harmful (which should be met with caution)?

\begin{tabular}{|llr}
\hline (a) Beneficial & 114 & $61.62 \%$ \\
\hline (b) Harmful & 43 & $23.24 \%$ \\
\hline (c) Not applicable & 28 & $15.14 \%$ \\
\hline
\end{tabular}

6. Are specific scientific studies mentioned in the Number Percentage of relevant articles $(\mathrm{n}=185)$ article?

(a) Yes

$108 \quad 58.38 \%$

(b) No

77

7. If 'yes' in \#6, is the name of the journal, institution, Number $41.62 \%$ authors or website provided (click on link if provided)?

\begin{tabular}{|c|c|c|}
\hline (a) Yes & 91 & $84.26 \%$ \\
\hline (b) No & 17 & $15.74 \%$ \\
\hline $\begin{array}{l}\text { 8. If a scientific study appears in the article, are claims } \\
\text { of efficacy of the science made? }\end{array}$ & Number & Percentage of articles mentioning studies $(n=108)$ \\
\hline (a) Yes & 68 & $62.96 \%$ \\
\hline (b) No & 40 & $37.04 \%$ \\
\hline $\begin{array}{l}\text { 9. Do any statements/claims in the headline seem } \\
\text { particularly focused on creating fear, distrust or } \\
\text { suspicion? }\end{array}$ & Number & Percentage of relevant articles $(n=185)$ \\
\hline (a) Yes & 30 & $16.22 \%$ \\
\hline (b) No & 155 & $83.78 \%$ \\
\hline $\begin{array}{l}\text { 10. Do any statements/claims in the rest of the article } \\
\text { seem focused on creating fear, distrust or suspicion? }\end{array}$ & Number & Percentage of relevant articles $(n=185)$ \\
\hline (a) Yes & 49 & $26.49 \%$ \\
\hline (b) No & 136 & $73.51 \%$ \\
\hline
\end{tabular}

Table 3. Selected examples of claims of efficacy.

Web domain

beforeitsnews.com

collective-evolution.com

collective-evolution.com

collective-evolution.com

healthimpactnews.com

healthimpactnews.com

healthnutnews.com

naturalblaze.com

naturalnews.com

naturalnews.com

\section{Example of claim}

The pain was far milder in the group of people whose limbs were wrapped by aluminum foil compared to the group in which such a therapy was not applied

In breast cancer, radiation treatment just drives breast cancer cells into greater malignancy and can make them up to 30 times more malignant

Cycles of prolonged fasting protect against immune system damage and induce immune system regeneration

A woman with special abilities was and is able to accelerate the germination of specific seeds for the purposes of developing a more robust seed stock

Yeast Is a cause of cancer And turmeric can kill both, research confirms

Forbidden cures: avocados and purple potatoes kill cancer cells

Grow new teeth with stem-cell dental implants!

Thus, black pepper can increase the bioavailability of the cancer, inflammation and infection fighter, curcumin, up to two thousand percent

There's a simple vitamin that holds the key to restoring your stem cells and mitochondria to a biologically younger state

Five-day 'fasting' diet miraculously slows aging, can prevent death from heart disease, cancer and diabetes

\section{Discussion}

Many of the web domains retold the same essential content across multiple articles with slightly different wording, and hyperlinked to many other articles or websites. For example, we noticed an abundance of (almost identical) stories on the topics of growing teeth naturally, natural substances curing cancer (such as turmeric, curcumin, ginger and avocado) and Planned Parenthood 'controversies'. Indeed, as mentioned, at least 123 (54.47\%) of the articles referenced health blogs, websites and alternative media. Despite our inability to concretely flag each of these sources 
Table 4. Selected examples of headlines appearing to be focused on creating fear, distrust or suspicion

\begin{tabular}{|c|c|}
\hline Web domain & Headline example \\
\hline beforeitsnews.com & $\begin{array}{l}\text { Scary as hell! Soul-less human-animal chimeras now grown On U.S. research farms! } \\
\text { (Videos) }\end{array}$ \\
\hline beforeitsnews.com & Horrifying! Part human, part animal hybrid embryos! \\
\hline dailyheadlines.net & Obama approves plans to create animal-human hybrid monsters \\
\hline healthimpactnews.com & $\begin{array}{l}\text { Avoid having your children medically kidnapped by the corrupt cancer industry - } \\
\text { FREE online seminar! }\end{array}$ \\
\hline naturalnews.com & Fraud in medical research: a frightening, all-too-common trend on the rise \\
\hline naturalnews.com & $\begin{array}{l}\text { STATINS RED ALERT: Widely prescribed drugs act as cellular poisons that accelerate } \\
\text { aging... deactivate DNA repair... promote diabetes, muscle fatigue and memory loss }\end{array}$ \\
\hline naturalnews.com & $\begin{array}{l}\text { The } 20 \text { biggest cancer lies you've been brainwashed to believe by the criminal } \\
\text { fraudsters who run the for-profit cancer industry }\end{array}$ \\
\hline naturalnews.com & $\begin{array}{l}\text { SICK: Chinese biotech company to start selling genetically modified miniature pigs } \\
\text { as pets }\end{array}$ \\
\hline naturalnews.com & $\begin{array}{l}\text { Doctors admit flu vaccines are useless to people taking statin drugs - and both cause } \\
\text { brain damage! }\end{array}$ \\
\hline thecontroversialfiles.net & McDonald's \& Burger King using dead aborted human fetuses in their food? \\
\hline
\end{tabular}

as problematic with regards to the creation and dissemination of distorted and/or dubious information, two of the four websites making up nearly $55 \%$ of the total 123 appeared on our 'junksci'list. The other two include the website of Dr Mercola [51], which was flagged by the American Council on Science and Health and RealClearScience as 'pure garbage' [17], and GreenMedInfo [52], a relative unknown that also contains strong antivaccination rhetoric. This clustering of alternative media stories through self-referential behavior and the replication of similar or identical stories could create the false impression of diverse source material, and has been previously observed in analyses of the spread of conspiracy-related stories on fake news websites [53]. Although further study is required, we speculate this type of collaborative linking between websites is partially done to generate more clicks and thus greater revenue from advertisements. Furthermore, it could contribute to the impression of a wealth of literature on a particular topic, which may further intensify the effects of 'echo chambers' or confirmation bias among those using the internet as a tool for self-education [34,35,54-56].

We noted a common theme on many of the websites, which was that natural products are much more effective and/or safe than conventional medical treatments, and that this fact is being hidden by the existing medical establishment. This argument often appeared in the $28.65 \%$ of articles in which stem cells were mentioned in relation to cancer. In several articles, ginger, curcumin and/or turmeric were described as much more effective at targeting and destroying cancer stem cells than conventional cancer treatments such as chemotherapy, and the authors added that the 'cancer industry' does not want patients to know about these natural solutions because it profits from keeping patients sick. In many cases, studies from reputable scientific journals were mentioned in support of these natural product claims, but the results of these studies were wildly exaggerated or misinterpreted. For example, one article in Health Nut News [57] cited a 2015 PLoS ONE study by Ray, Vasudevan and Sengupta [58] in which the researchers concluded that "the ginger product 6-shogaol was effective in breast cancer cells in monolayer culture and spheroid culture in comparable concentrations and in conditions where taxol, even though highly effective in monolayer cells, was completely ineffective" [58]. The headline of the Health Nut News article was "NEW STUDY SHOWS GINGER IS 10,000X STRONGER THAN CHEMO (AND ONLY KILLS CANCER CELLS)" [57]. The author also concluded that "more research needs to be done so we can show that modern cancer medicine is not as effective as natural medicine; making our bodies sick while trying to cure a disease is simply not enough anymore" [57]. Indeed, the science cited was only marginally related to the unsupported claims of the article.

In some cases, we noted political and religious themes (especially among the $22.70 \%$ of articles with central topics relating to ethical, legal and social issues), usually in articles criticizing or stoking fear around the American government or government-funded institutions like Planned Parenthood. President Barack Obama was mentioned in several articles in a negative context. For example, an article from Before It's News is titled "Obama Openly Promotes the Murder of Babies and Harvesting of Live Babies' Organs" and encourages readers to "start praying imprecatory prayers not only against Barack Obama, but also all those who support the murder and dismemberment of babies" [59]. 
Interestingly, sometimes the same web domains contained both articles that promoted stem cell research and benefits through exaggeration, and articles that casted doubt on the stem cell research enterprise and stoked fear around any stem cell advances. The contradictory nature of this messaging could help to fuel a polarization of the public discourse around stems cells by creating the impression that everything is either a disaster or a breakthrough. This, in turn, would make it more difficult for the public to accurately interpret news that takes an evidence-based approach to interpreting science [60].

\section{Conclusion}

In a sense, these results are consistent with analyses of stem cell representations by marketers and news media, in that the most common characteristics of online representations are exaggeration of scientific findings and/or their importance, hyping of new therapies and uncritical optimism $[21,47,48]$. The articles studied appear at face value to greatly skew their source information, but fact-checking of individual articles was not within the scope of this research. It is also clear that alternative motives are often present in relation to articles' manner of presentation; as mentioned, articles often contained statements unfavorable toward conventional medicine and the health industry, and many articles seemed to be structured for revenue generation.

Given what the evidence says about the potential effects of fake or misleading news, the claims we found were alarming. Such claims could have an impact on both public perceptions and ultimately on the formation of policy. It is important that the research community be aware of the phenomenon of fake news in the context of stem cell science. Public perceptions and attitudes have the ability to affect the trajectories not only of new stem cell technologies but of the entire stem cell research enterprise. Indeed, even misconceptions about stem cells borne from inaccurate articles on topics unrelated to current regenerative medicine research could affect broader public opinion of stem cells, and public opinion influences policy [61]. As such, public awareness campaigns and other steps could be taken to help counteract these publishers. Indeed, governments could fund endeavors to help educate the public on how to carefully and skeptically read online health news stories [62]. Curtailing the influence of fake news and junk science websites will help to ensure that the future of stem cell research, policy and public opinion is one that reflects an evidence-based perspective, rather than one contaminated by muddled thinking.

\section{Future perspective}

The path that fake stem cell related news will take in 5-10 years depends greatly upon the policy response undertaken to curb the spread of misinformation. A significant percentage of the flow of internet activity and online information is now controlled by a very small number of corporations, the most notable being Google, Facebook and Twitter. These companies may not be willing to take the necessary steps to identify and curb the spread of fake news, or their ability to do so could be substantially curtailed by law and public opinion surrounding freedom of speech. In our view, governments and research institutions have a responsibility to create policies that discourage or restrict the spread of misinformation, while still respecting free speech. In addition, the research community should do their best to counter misinformation about stem cell research and unproven therapies. While a challenging task, these moves may help to slow the spread of misinformation. In the absence of sufficient public or corporate policy action to curb the spread of fake news online, fake news will likely spread, causing increased public confusion regarding stem cells. In this scenario, fake news seems likely to contribute to a polarized and flawed public discourse about the risks and benefits of stem cell research.

\section{Disclaimer}

The opinions expressed in this article are those of the authors and do not necessarily reflect the views of Future Medicine Ltd.

\footnotetext{
Financial \& competing interests disclosure

This research was funded by the Stem Cell Network. The authors would like to thank J Vivian for her help with coding the sample, and R Hyde-Lay for her various efforts relating to the acquisition of funding for this project. The authors have no other relevant affiliations or financial involvement with any organization or entity with a financial interest in or financial conflict with the subject matter or materials discussed in the manuscript apart from those disclosed.

No writing assistance was utilized in the production of this manuscript.
} 


\section{Summary points}

- Stem cells or stem cell research discussed in articles from fake news websites in the years 2015 and 2016 were most commonly discussed in articles with the following central topics: general science and research; therapies to treat diseases or ailments; ethical, legal and social issues including government and institutional actions and policies; and products or substances for health promotion or anti-aging.

- Ethical, legal and social issues most commonly raised, included unethical research, harmful government policies and actions, crime and nefarious activity unrelated to the government, and religious themes.

- Stem cells were most commonly discussed in the context of cancer, growing or fixing body parts, general health or wellness related to diet and stopping or reversing noncosmetic aging processes.

- More than half of the articles made reference to specific studies, and more than $80 \%$ of these articles included information about the studies.

- Certain articles contained exaggerated or highly inaccurate claims when referencing specific scientific publications.

- Articles often included source material from other health blogs, health websites, or alternative media outlets.

- Numerous articles made statements promoting fear and mistrust of medical practices, government and specific politicians.

- The stem cell news created on these websites is alarming and could have repercussions for the general public seeking sound scientific information.

\section{Ethical conduct of research}

The authors state that they have obtained appropriate institutional review board approval or have followed the principles outlined in the Declaration of Helsinki for all human or animal experimental investigations. In addition, for investigations involving human subjects, informed consent has been obtained from the participants involved.

\section{Open access}

This work is licensed under the Attribution-NonCommercial-NoDerivatives 4.0 Unported License. To view a copy of this license, visit http://creativecommons.org/licenses/by-nc-nd/4.0/

\section{References}

1. Darnton R. The True History of Fake News. The New York Review of Books (2017). www.nybooks.com/daily/2017/02/13/the-true-history-of-fake-news/

2. Soll J. The Long and Brutal History of Fake News. Politico Magazine (2016). www.politico.com/magazine/story/2016/12/fake-news-history-long-violent-214535

3. Platt B. Platt: In an era of fake news, the Ontario Liberals are making things worse. Ottawa Citizen (2017). http://ottawacitizen.com/opinion/columnists/platt-in-an-era-of-fake-news-the-ontario-liberals-are-making-things-worse

4. Barron J. In an Era of Fake News, Teaching Students to Parse Fact From Fiction. The New York Times (2017). www.nytimes.com/2017/03/20/nyregion/fake-news-brooklyn-middle-school.html

5. Oremus W. Why the White House Keeps Crying 'Fake News'. Slate (2017). www.slate.com/articles/technology/technology/2017/02/why_the_white_house_keeps_crying_fake_news.html

6. Nelson L. Trump tweets NBC, ABC broadcast 'biased and fake' Russia Stories. Politico (2017). www.politico.com/story/2017/03/trump-tweet-nbc-abc-russia-fake-news-236407

7. Mulcair lambastes Trudeau for 'fake news' political advertisements. Global News (2017). http://globalnews.ca/video/3293567/mulcair-lambastes-trudeau-for-fake-news-political-advertisments

8. Gorzelany J. Quality Issues Are 'Fake News' To Tesla Owners. Forbes (2017). www.forbes.com/sites/jimgorzelany/2017/03/23/quality-issues-are-fake-news-to-tesla-owners/\#5c25281177c0

9. Silverman C. This Analysis Shows How Viral Fake Election News Stories Outperformed Real News on Facebook. BuzzFeed News (2016). www.buzzfeed.com/craigsilverman/viral-fake-election-news-outperformed-real-news-on-facebook?utm_term=.aa49e53E6\#.lqp8rov5G

10. Gordon G. Opinion: Canada's government shouldn't be in the business of policing 'fake news'. CBC (2017). www.cbc.ca/news/opinion/government-fake-news- 1.3993128

11. Kosoff M. There is no good answer to Facebook's fake-news problem. Vanity Fair (2016). www.vanityfair.com/news/2016/12/there-is-no-good-answer-to-facebooks-fake-news-problem

12. Romano A. Facebook is fighting fake news by making it harder - or at least more annoying - to share. Vox (2017). www.vox.com/culture/2017/3/24/15020806/facebook-fake-news-alert-fact-checking 
13. Wakabayashi D, Isaac M. In Race Against Fake News, Google and Facebook Stroll to the Starting Line. The New York Times (2017). www.nytimes.com/2017/01/25/technology/google-facebook-fake-news.html

14. Oransky I, Marcus A. Fake news invades science and science journalism as well as politics. STAT (2016). www.statnews.com/2016/12/30/fake-news-science/

15. Cambridge scientists consider fake news 'vaccine'. BBC News UK (2017). www.bbc.com/news/uk-38714404

16. Barthel M, Mitchell A, Holcomb J. Many Americans Believe Fake News Is Sowing Confusion. Pew Research Center (2016). www.journalism.org/2016/12/15/many-americans-believe-fake-news-is-sowing-confusion/

17. Science journalism can be evidence-based, compelling - and wrong. Nature Editorial (2017). www.nature.com/news/science-journalism-can-be-evidence-based-compelling-and-wrong-1.21591?WT.mc_id=FBK_NatureNews

18. Caulfield T, Condit C. Science and the sources of hype. Public Health Genomics. 15(3-4), 209-217 (2012).

19. Caulfield T, Sipp D, Murry CE, Daley GQ, Kimmelman J. Confronting stem cell hype. Science 352(6287), 776-777 (2016).

20. Du L, Rachul C, Guo Z, Caulfield T. Gordie Howe's 'Miraculous Treatment': case study of Twitter users' reactions to a sport celebrity's stem cell treatment. JMIR Public Health Surveill. 2(1), e8 (2016).

21. Rachul C, Caulfield T. Gordie Howe's stem cell 'Miracle': a qualitative analysis of news coverage and readers' comments in newspapers and sports websites. Stem Cell Rev. 11(5), 667-675 (2015).

22. Hunt E. What is fake news? How to spot it and what you can do to stop it. The Guardian (2016). www.theguardian.com/media/2016/dec/18/what-is-fake-news-pizzagate

23. McCoy T. For the 'new yellow journalists,' opportunity comes in clicks and bucks. The Washington Post (2016). www.washingtonpost.com/national/for-the-new-yellow-journalists-opportunity-comes-in-clicks-and-bucks/2016/11/20/d58d036cadbf-11e6--8b45-f8e493f06fcd_story.html?utm_term=.6b69176b08bf

24. Reis J, Benevenuto F, Vaz de Melo POS, Prates R, Kwak H, An J. Breaking the News: First Impressions Matter on Online News. arXiv:1503.07921v2 [cs.CY] (2015). https://arxiv.org/abs/1503.07921

25. Souppouris A. Clickbait, fake news and the power of feeling. Engadget (2016). www.engadget.com/2016/11/21/clickbait-fake-news-and-the-power-of-feeling/

26. Blom JN, Hansen KR. Click bait: forward-reference as lure in online news headlines. J. Prag. 76, 87-100 (2015).

27. Escher A. WTF is clickbait? TechCrunch (2016). https://techcrunch.com/2016/09/25/wtf-is-clickbait/

28. O’Donovan C. What is clickbait? NiemanLab (2014). www.niemanlab.org/2014/08/what-is-clickbait/

29. Sydell L. We Tracked Down A Fake-News Creator In The Suburbs. Here's What We Learned. NPR (2016). www.npr.org/sections/alltechconsidered/2016/11/23/503146770/npr-finds-the-head-of-a-covert-fake-news-operation-in-the-suburbs

30. Senapathy K. NaturalNonsense: Science Supporters Condemn Natural News Founder Mike Adams. Forbes (2016). www.forbes.com/sites/kavinsenapathy/2016/12/23/naturalnonsense-friends-dont-let-friends-read-natural-news/\#314235db6753

31. OpenSources. Professionally curated lists of online sources, available free for public use. www.opensources.co/

32. Owen LH. Clamping down on viral fake news, Facebook partners with sites like Snopes and adds new user reporting. NiemanLab (2016). www.niemanlab.org/2016/12/clamping-down-on-viral-fake-news-facebook-partners-with-sites-likesnopes-and-adds-new-user-reporting/

33. World Health Organization Regional Office for Europe. The Solid Facts: Health Literacy (2013). www.euro.who.int/_data/assets/pdf_file/0008/190655/e96854.pdf

34. Hart W et al. Feeling validated versus being correct: a meta-analysis of selective exposure to information. Psychol. Bull. 135(4), 555-588 (2009).

35. Vicario MD et al. Echo Chambers in the age of misinformation. Echo-ArXiv 5(43), 1-6 (2015).

36. Tan AS, Lee CJ, Chae J. Exposure to health (Mis)information: lagged effects on young adults' health behaviors and potential pathways. J. Commun. 65(4), 674-698 (2015).

37. Chen MF, Wang RH, Schneider JK et al. Using the health belief model to understand caregiver factors influencing childhood influenza vaccinations. J. Commun. Health Nurs. 28(1), 29-40 (2011).

38. Dunn AG, Leask J, Zhou X, Mandl KD, Coiera E. Associations between exposure to and expression of negative opinions about human papillomavirus vaccines on social media: an observational study. J. Med. Internet Res. 17(6), e144 (2015).

39. Brunson EK. The impact of social networks on parents' vaccination decisions. Pediatrics 131(5), E1397-E1404 (2013).

40. Kata A. Anti-vaccine activists, Web 2.0 and the postmodern paradigm - an overview of tactics and tropes used online by the antivaccination movement. Vaccine 30(25), 3778-3789 (2012).

41. Dixon G, Clarke C. The effect of falsely balanced reporting of the autism - vaccine controversy on vaccine safety perceptions and behavioral intentions. Health Educ. Res. 28(2), 352-359 (2013).

42. Dixon G, Clarke C. Heightening uncertainty around certain science media coverage, false balance and the autism-vaccine controversy. Sci. Commun. 35(3), 358-382 (2013). 
43. Jolley D, Douglas KM. The effects of antivaccine conspiracy theories on vaccination intentions. PLoS ONE 9(2), e89177 (2014).

44. Goertzel T. Conspiracy theories in science. EMBO Reports 11(7), 493 (2010).

45. Thorson E. Belief echoes: the persistent effects of corrected misinformation. Polit. Commun. 33(3), 460-480 (2016).

46. Pennycook G, Cannon T, Rand D. Prior Exposure Increases Perceived Accuracy of Fake News. SSRN (2017). http://ssrn.com/abstract=2958246

47. Turner L, Knoepfler P. Selling stem cells in the USA: assessing the direct-to-consumer industry. Cell Stem Cell 19(2), 154-157 (2016).

48. Lau D, Ogbogu U, Taylor B, Stafinski T, Menon D, Caulfield T. Stem cell clinics online: the direct-to-consumer portrayal of stem cell medicine. Cell Stem Cell 3(6), 591-594 (2008).

49. Ogbogu U, Rachul C, Caulfield T. Reassessing direct-to-consumer portrayals of unproven stem cell therapies: is it getting better? Regen. Med. 8(3), 361-369 (2013).

50. Elo S, Kyngäs H. The qualitative content analysis process. J. Adv. Nurs. 62(1), 107-115 (2008).

51. Mercola. www.mercola.com

52. GreenMedInfo. www.greenmedinfo.com

53. Starbird K. Information Wars: A Window into the Alternative Media Ecosystem. Medium (2017). https://medium.com/hci-design-at-uw/information-wars-a-window-into-the-alternative-media-ecosystem-a1347f32fd8f

54. Del Vicario M, Bessi A, Zollo F et al. The spreading of misinformation online. Proc. Natl Acad. Sci. USA 113(3), 554-559 (2016).

55. Browne M, Thomson P, Rockloff MJ, Pennycook G. Going against the herd: psychological and cultural factors underlying the 'vaccination confidence gap'. PLoS ONE 10(9), e0132562 (2015).

56. Stanovich KE, West RF, Toplak ME. Myside bias, rational thinking and intelligence. Curr. Dir. Psychol. Sci. 22(4), 259-264 (2013).

57. Ji S. New Study Shows Ginger IS 10,000X Stronger than Chemo (and only Kills Cancer Cells). Health Nut News (2015). www.healthnutnews.com/new-study-shows- ginger-is-10000x-stronger-than-chemo-and-only-kills-cancer-cells/

58. Ray A, Vasudevan S, Sengupta S. 6-Shogaol inhibits breast cancer cells and stem cell-like spheroids by modulation of notch signaling pathway and inductions of autophagic cell death. PLoS ONE 10(9), e0137614 (2015).

59. Before It's News. Obama Openly Promotes the Murder of Babies' and Harvesting of Live Babies' Organs. Before It's News (2015). http: //beforeitsnews.com/politics/2015/09/obama-openly-promotes-the-murder-of-babies-harvesting-of-live-babies-organs-2743260.html

60. Pomerantsev P, Weiss M. The Menace of Ureality: How the Kremlin Weaponizes Information, Culture and Money. Institute of Modern Russia (2014). http://cdn.mashreghnews.ir/old/files/fa/news/1393/12/26/950303_869.pdf

61. Burstein P. The impact of public opinion on public policy: a review and an agenda. Polit. Res. Q. 56(1), 29-40 (2003).

62. Schwitzer G. A guide to reading healthcare news stories. JAMA Intern. Med. 174(7), 1183-1186 (2014). 